\title{
PROSTITUSI REMAJA DAN KETAHANANAN KELUARGA
}

\author{
Ulfiah \\ ulfiah@uinsgd.ac.id \\ Neng Hannah \\ UIN Sunan Gunung Djati Bandung UIN Sunan Gunung Djati Bandung
}

\begin{abstract}
The aim of this research were; first, to show to the phenomenon of teenage girl prostitution in Cianjur seen from the characteristics of prostitution place, the characteristics of perpetrator and victim, as well as the prostitution mechanism that happened. The second one is to know how the condition of the teenage girl's family tenacity that became the victim. This research used descriptive analysis method by examining theory as a phenomenon on the field with qualitative approach that aim to uncover the reality of what happened to the teenage girls involved in prostitution. The data found were then analyzed with Foucault genealogy method, so that the researcher could identify of which authorities that related with the teenage girl prostitution phenomenon and family resilience. The result showed that the teenage girls prostitution in Cianjur seen from the characteristics of prostitution place, the characteristics of perpetrator and victim, as well as the prostitution mechanism that happened; there were four kinds of child traffickers for prostitution, namely significant others, friends, and pimps.
\end{abstract}

Keywords: teenage girl prostitution, family resilience

\begin{abstract}
Abstrak
Tujuan penelitian ini adalah; pertama, untuk mengungkapkan fenomena prostitusi remaja putri di Cianjur dilihat dari karakteristik tempat prostitusi, karakteristik pelaku dan korban serta mekanisme prostitusi yang terjadi; dan kedua, untuk mengetahui bagaimana kondisi ketahanan keluarga remaja putri yang menjadi korban. Penelitian ini menggunakan metode deskriptif analisis dengan menguji teori sebagai sebuah fenomena di lapangan melalui pendekatan kualitatif yang bertujuan untuk mengungkap realita yang terjadi pada remaja putri yang terlibat pada kegiatan prostitusi. Temuan hasil lapangan kemudian dianalisis dengan metode genealogi Foucault sehingga peneliti mengidentifikasi kekuasaan-kekuasaan apa/mana saja yang berkaitan dengan fenomena prostitusi remaja putri dan ketahanan keluarga. Hasil penelitian diperoleh bahwa, Prostitusi remaja putri di Cianjur dilihat dari karakteristik tempat prostitusi, karakteristik pelaku dan korban serta mekanisme prostitusi yang terjadi. Pada penelitian ini ditemukan ada empat macam pelaku perdagangan anak untuk prostitusi, yaitu pacar, teman, dan mucikari.
\end{abstract}

Kata kunci: Prostitusi remaja dan ketahanan keluarga 


\section{PENDAHULUAN}

"Satreskrim Polres Cianjur telah melakukan penangkapan terhadap yang diduga tindak pidana perdagangan orang dan prostitusi online di bawah umur," kata Kepala Bidang Humas Polda Jabar Kombespol Yusri Yunus kepada wartawan Kamis (2/6/2016). Sembilan remaja putri menjadi korban prostitusi online. Tiga dari remaja putri ini merupakan penduduk desa Ramasari Haurwangi Cianjur. Kasus ini menambah panjang daftar perkara perdagangan anak untuk tujuan eksploitasi seksual. Menteri Negara Pemberdayaan Perempuan dan Perlindungan Anak, Yohana Yembise dalam Rapat Koordinasi Nasional Gugus Tugas Tindak Pidana Perdagangan Orang (TPPO) yang berlangsung di Jakarta pada tanggal 23 sampai 25 Agustus 2015, menyatakan bahwa menurut data Mahkamah Agung, Indonesia merupakan negara dengan TPPO nomor tiga terbanyak di dunia.

Bareskrim Polri juga mencatat 861 kasus perdagangan orang dan 70 persen korban adalah perempuan dan anak selama kurun waktu 2012 sampai Mei 2015. Komisi Perlindungan Anak Indonesia (KPAI) mencatat dalam kurun waktu lima tahun terakhir, kasus perdagangan dan eksploitasi anak mengalami peningkatan, dari 160 kasus pada 2011, 173 pada 2012, 184 kasus tahun 2013 meningkat menjadi 263 kasus di tahun 2014 dan menjadi 345 kasus pada 2015. Dari total 1.125 kasus tersebut, anak sebagai korban perdagangan berjumlah 252 kasus, anak sebagai korban prostitusi online sebanyak 303 kasus, dan anak yang mengalami eksploitasi seks komersial berjumlah 265 kasus.

Masalah remaja putri yang diperdagangkan kemudian menjadi korban prostitusi memang sangat kompleks karena tidak hanya terkait faktor ekonomi, namun telah meluas ke masalah sosial, politik, dan budaya. Remaja putri yang menjadi korban prostitusi identik dengan kemiskinan. Pada kasus 9 remaja putri di Cianjur, tidak semuanya disebabkan dorongan ekonomi. Beberapa mengaku memiliki masalah dengan keluarga. Renggangnya hubungan dengan keluarga menyebabkan orang tua kehilangan kendali dalam pengawasan anak-anak, sehingga dimanfaatkan oleh pihak-pihak yang tidak bertanggung jawab.

KPAI pernah merilis temuan terkait perdagangan anak pada tahun 2014, dengan menitikberatkan peran keluarga yang melatarbelakangi kasuskasus perdagangan anak. Selain kurangnya kesadaran untuk melindungi anak, kemiskinan keluarga, ada juga pengaruh peran anak dalam keluarga yang dijadikan salah satu unit ekonomi untuk menopang kehidupan keluarga. Oleh karena itu, tampaknya permasalahan prostitusi remaja putri ini perlu diusut dari kualitas keluarga terutama terkait dengan psikologi keluarga. 
Secara umum setiap keluarga memiliki sejumlah fungsi. Zastrow (1993) membagi fungsi keluarga menjadi lima, yaitu:

(1) Replacement of the population, yaitu fungsi keluarga untuk melanjutkan keturunan; (2) Care of the young, yaitu fungsi pengasuhan dan perawatan terhadap anakanak; (3) Socialization of new members, yaitu fungsi untuk menyosialisasikan nilainilai budaya, norma, dan bahasa kepada anggota keluarganya; (4) Regulation of social behavior, yaitu fungsi pengaturan perilaku seksual; (5) Source of affection, yaitu fungsi untuk memberikan kasih sayang. Berjalannya fungsi-fungsi tersebut dalam keluarga akan melahirkan individuindividu yang sehat secara fisik, sosial, dan psikologi. Apabila salah satu dari kelima fungsi keluarga tersebut tidak dapat dilaksanakan maka keluarga rentan mengalami kerapuhan.

Dewasa ini, keluarga mengalami perubahan struktur dan fungsi seiring terjadinya perubahan sosial pada masyarakat. Secara struktur, saat ini keluarga cenderung merupakan "nuclear family" (keluarga inti yang terdiri dari ayah, ibu, dan anak), bukan lagi "extended family" (keluarga batih yang terdiri dari ayah, ibu, anak, kakek, nenek, paman, dan bibi). Secara fungsi, dari kelima fungsi seperti yang disebut Zastrow mengalami pergeseran. Seperti fungsi pengasuhan dan perawatan yang tidak lagi dilakukan oleh orang tua (ayah dan ibu) tetapi oleh asisten rumah tangga. Perubahan-perubahan ini telah menggoyahkan eksistensi keluarga sehingga keluarga rentan kegoncangan atau mudah mengalami disorganisasi. Fenomena perdagangan anak, menurut Suradi (2013) adalah "indikasi tidak berjalannya fungsi keluarga". Corak kehidupan materialistis dan individualistis, memasuki kehidupan sebagian keluarga di Indonesia. Komunikasi dan interaksi sosial antara orang tua dan anak menjadi terbatas dan kurang berkualitas. Akibatnya proses tumbuh kembang anak akan terganggu. Suradi menyebut kondisi ini sebagai isolasi budaya dan isolasi ekonomi yang disebabkan oleh tingginya mobilitas keluarga. Dalam kondisi ini, keluarga akan semakin sulit untuk memelihara hubungan sosial. Selain itu, perubahan sosial tersebut mendorong ke arah kehidupan modern yang bertentangan dengan pemeliharaan jaringan sosial bagi keluarga dan anakanaknya. Berangkat dari hal inilah penelitian tentang Prostitusi Remaja Putri dan Ketahanan Keluarga perlu dilakukan.

\section{METODE PENELITIAN}

Penelitian ini mengunakan pendekatan kualitatif yang bertujuan untuk mengungkap realita yang terjadi pada remaja putri yang terlibat prostitusi. Strauss dan Corbin mengatakan bahwa penelitian yang menggunakan pendekatan kualitatif memang dapat digunakan untuk mempelajari, membuka dan mengerti apa yang terjadi di belakang setiap 
fenomena yang baru sedikit diketahui. Begitupun dengan fenomena prostitusi remaja dan ketahanan keluarga. Karena itulah kami memandang penting menggunakan pendekatan kualitatif agar dapat mengungkapkan sebuah fenomena prostitusi remaja putri dan ketahanan keluarga di Cianjur. Dengan mengkajinya akan dapat dipelajari kenapa fenomena prostitusi remaja ini terjadi dan angkanya cukup tinggi di Jawa Barat. Sehingga langkah selanjutnya dapat mencari upaya perbaikan situasi perempuan ke arah yang lebih baik.

Penelitian dengan pendekatan kualitatif ini juga menggunakan perspektif perempuan yang menjadikan pengalaman perempuan menjadi fokus perhatian utama. Berbeda dari penelitian yang bersifat umum, penelitian kualitatif berperspektif perempuan secara eksplisit menyatakan keberpihakannya. Penelitian yang berperspektif perempuan mempertanyakan metodologi penelitian konvensional yang dianggap terlalu male bias (bias laki-laki). Dale Spender mengatakan:

Di jantung pemikiran feminis adalah pemahaman yang sangat penting bahwa tidak ada satu kebenaran, satu otoritas, satu metode objektif yang mengarah pada produksi pengetahuan murni. Pemahaman ini bisa berlaku baik untuk pengetahuan feminis maupun ilmu pengetahuan patriarkhis, namun ada perbedaan yang sangat penting di antara keduanya: ilmu pengetahuan feminis berdasarkan suatu premis bahwa pengalaman semua manusia adalah valid dan tidak boleh dibuang dari pemahaman kita, sementara pengetahuan patriarkis berdasarkan pada premis bahwa pengalaman dari hanya separuh penduduk dunia (laki-laki) perlu dipertimbangkan dan versi yang dihasilkan dari situ bisa diterapkan pada pihak satunya, separuh penduduk dunia lainnya (perempuan). Inilah sebabnya mengapa ilmu pengetahuan patriarkis dan metode-metode yang menghasilkannya merupakan bagian pokok penindasan perempuan, dan mengapa ilmu pengetahuan patriarkis harus digugat dan ditolak.

Lokasi yang dipilih pada penelitian ini ialah Kabupaten Cianjur Jawa Barat. Alasan kenapa lokasi ini di pilih, karena Cianjur merupakan daerah wisata yang menjadi tujuan banyak turis mancanegara dan dalam negri. Fenomena prostitusi remaja banyak ditemukan disini. Selain juga Cianjur dalam laporan Badan Pusat Statistik Jawa Barat memiliki usia rata-rata sekolah kedua terbawah setelah Majalengka. Padahal Cianjur merupakan Kabupaten yang kaya akan sumber daya alam.

Sumber data utama dalam penelitian tentang fenomena prostitusi remaja putri dan ketahanan keluarga di Cianjur ini ialah lima remaja putri yang terlibat dalam praktik prostitusi dan keluarganya.. Pilihan pada lima informan utama ini peneliti lakukan dengan tujuan agar permasalahan yang diteliti dapat dikaji lebih mendalam dan terfokus. Peneliti tidak 
menggunakan sampel yang besar karena menurut Sarantakos sebagaimana dikutip oleh Kristi Poerwandari:

Prosedur penentuan subjek dan atau sumber data dalam penelitian kualitatif umumnya menampilkan tiga karakteristik sebagai berikut: Pertama, diarahkan tidak pada jumlah sampel yang besar, melainkan pada kasus-kasus tipikal sesuai kekhususan masalah penelitian. Kedua, tidak ditentukan secara kaku sejak awal tetapi dapat berubah baik dalam hal jumlah maupun karakteristik sampelnya, sesuai dengan pemahaman konseptual yang berkembang dalam penelitian dan ketiga, tidak diarahkan pada keterwakilan dalam arti jumlah atau peristiwa acak, melainkan pada kecocokan konteks.

Saat menentukan informan, peneliti hanya memilih informan yang mewakili kondisi tertentu yaitu remaja putri yang menjadi korban prostitusi. Sebagaimana Patton yang dikutip Kristi Poerwandari menyebutnya sebagai sampel kasus tipikal. Pengambilan sampel ini tidak peneliti maksudkan untuk tujuan generalisasi akan tetapi bersifat ilustratif, yaitu memberi gambaran tentang kelompok yang dianggap dapat mewakili sebuah fenomena yang dteliti. Sehingga pemilihan sampel didasarkan karena informan dan lokasi tersebut secara tipikal mewakili fenomena yang diteliti.

Untuk memperdalam pengetahuan pada beberapa informan, dilakukan wawancara informal kepada keluarga korban dan proses wawancara didasarkan sepenuhnya pada berkembangnya pertanyaan secara spontan dalam interaksi alamiah. Wawancara informal yang akan kami lakukan adalah kepada keluarga informan, bisa kepada ibu, ayah, kakak atau adik atau kerabat informan.

Di dalam keseluruhan proses pengambilan data, digunakan metode observasi untuk memperkuat pemahaman pada konteks masalah. Patton sebagaimana dikutip oleh E.Kristi Poerwandari menyebutkan, "pentingnya observasi dalam sebuah penelitian kualitatif untuk mendapatkan data yang bermanfaat dan akurat sehingga dapat merefleksikan pemikiran subjek penelitian tentang pengalamannya dan mengungkapkan hal-hal yang belum dikemukakan dalam proses wawancara". Hal ini sejalan dengan pandangan Bungin yang mengatakan:

Teknik analisis data yang digunakan dalam penelitian ini dilakukan dengan menggunakan teknik analisis gabungan antara induktif dengan deduktif yang mengembangkan kategori-kategori analisis berdasarkan gabungan dari pertanyaan penelitian, teori, penelitian terdahulu dan data. Sehingga diharapkan kekayaan fenomena dapat dipotret dan ditampikan seutuh mungkin. 
Teknik Analisis data dari hasil lapangan ini kemudian menggunakan metode genealogi Foucault untuk mengdiagnosis saat ini (history of the present) yaitu:

1. Peneliti mengidentifikasi kekuasaan-kekuasaan apa/mana saja yang berkaitan dengan fenomena prostitusi remaja putri dan ketahanan keluarga.

2. Mencari unsur-unsur tersembunyi apa/mana yang biasanya tidak diperhitungkan namun sangat menentukan praktik prostitusi yang dialami oleh remaja putri.

3. Secara keseluruhan, penelitian ini ahirnya akan diharapkan akan melahirkan pandangan baru tentang fenomena prostitusi remaja putri dan ketahahan keluarga

Dengan menggunakan genealogi Foucault ini diharapkan, akan mampu menampilkan praktik dan norma yang menjadi realita di balik fakta yang tampil sebagai dokumen/teks yang dipandang sebagai bagian dari praktik sosial. Hal ini penting mengingat fokus penelitian ini menempatkan perempuan pada posisi terdiskriminasi, sehingga dengan analisis perspektif feminis akan memberikan hasil yang lebih berpihak pada penegakan hak asasi manusia, khususnya hak asasi perempuan.

\section{HASIL PENELITIAN}

\section{Karakteristik Pelaku Perdagangan Remaja Putri}

Praktik prostitusi remaja putri, pada dasarnya melibatkan beberapa pihak yang terorganisir yang sering disebut sindikat. Dalam hal ini paling tidak terdapat dua pihak yang terlibat yaitu korban atau remaja putri yang awalnya menjadi korban perdagangan anak dan pelaku. Dalam penelitian ini, ditemukan ada empat macam pelaku perdagangan anak untuk prostitusi, yaitu pacar, teman, dan mucikari. Bagi sebagian besar pelaku yang terlibat dalam perdagangan anak untuk prostitusi ini, keterlibatan mereka merupakan pekerjaan sampingan. Namun ada pula beberapa orang di antaranya yang menjadikan pekerjaan tetap. Para pelaku tidak mempunyai keterikatan formal apa pun dalam sindikat perdagangan anak dengan tujuan prostitusi ini.

\section{Pacar}

Pacar sebagai pelaku dalam perdagangan anak untuk prostitusi memiliki karakter yang dapat dibedakan dengan pelaku-pelaku lainnya. Untuk dapat menjerat korban, pacar sangat pandai mengambil hati sehingga korban sangat mudah percaya dan ahirnya terjebak oleh rayuan janji-janjinya.

D (29) tahun misalnya, berusaha menjerat Y korbannya saat berusia 14 tahun. Pertama tama dengan mengajaknya berkenalan ketika mereka bertemu di sebuah tempat wisata. Kepada Y, D mengaku berasal dari 
Jakarta dan saat ada di Cianjur karena ada tugas kantor yang harus diselesaikan. Setelah berhasil menarik perhatian dan meyakinkan Y, D pun memberanikan diri secara rutin menemui $\mathrm{Y}$ disekolahnya, sampai ahirnya resmi pacaran. Penampilan D yang sopan, sikapnya yang melindungi dan menjanjikan masa depan yang baik membuat $\mathrm{Y}$ menaruh kepercayaan kepadanya. Hubungan mereka pun semakin dekat dari hari ke hari.

Merasa bahwa si korban telah berhasil dijeratnya, pada suatu hari $\mathrm{D}$ menawari Y untuk berlibur ke kota Cianjur. Tawaran ini langsung disetujui Y. D mengajak Y menginap di hotel berbintang. Di hotel iniah D melakukan transaksi dengan sindikat perdagangan anak untuk prostitusi. Y dijual seharga Rp.7.00.000. Dari hasil penjualan tersebut, D mendapatkan tip dan bebas akomodasi hotel. Begitu transaksi selesai dilakukan, D segera menghilang meninggalkan $\mathrm{Y}$ dan sindikat perdagangan anak untuk pelacuran tersebut. $\mathrm{Y}$ dipertemukan dengan Mami $\mathrm{E}$ yang mengatur transaksi. Y sempat dikirim bekerja di Jakarta oleh orang suruhan Mami E selama hampir dua tahun. Karena sakit sakitan ahirnya Y dikembalikan ke Cianjur. Meski kesehatannya tidak begitu baik. Y kadang masih menerima tamu yang berminat padanya dengan jasa sindikat prostitusi di Cianjur.

Terkadang, pacar sebagai pelaku perdagangan anak untuk pelacuran ini dikenal oleh pihak korban seperti yang terjadi dalam kasus M (17). Pada awalnya $\mathrm{M}$ berpacaran dengan $\mathrm{T}$ (15) adik kelasnya saat dulu di SMP. Mereka berpacaran dalam waktu relatif lama. Diantara mereka sudah mengetahui rumah masing masing, bahkan keduanya pernah melakukan hubungan seks.

Belajar dari teman temannya yang dengan mudah mendapatkan banyak uang dengan cara menjual pacar, $M$ pun tergoda untuk melakukan hal yang sama. Ia kemudian memanfaatkan $\mathrm{T}$ untuk mendapatkan uang, yaitu dengan cara menjual $\mathrm{T}$ kepada laki-laki yang menginginkan pelayanan seks. Karena awalnya $\mathrm{T}$ menolak permintaan $\mathrm{M}, \mathrm{M}$ pun tidak tanggung tanggung mengeluarkan ancaman sehingga ahirnya $\mathrm{T}$ terpaksa mengikuti kemauannya.

Setelah $\mathrm{T}$ putus dengan $\mathrm{M}, \mathrm{T}$ pada ahirnya tidak bisa keluar dari dunia prostitusi. $\mathrm{T}$ menerima panggilan melayani seks laki-laki hidung belang dengan mandiri. Dia menggunakan media sosial dalam aktifitasnya di dunia prostitusi. $\mathrm{T}$ bebas menentukan berapa tarip, kuantitas melayani dan tempat terjadinya transaksi.

\section{Teman}

Dalam kasus teman sebagai pelaku perdagangan anak untuk tujuan prostitusi, korban sudah mengenal pelaku sebelumnya, baik sebagai tetangga, teman sekolah maupun teman sepermainan. Biasanya teman sebagai pelaku berusaha menjerat korbannya dengan pamer berbagai barang mahal yang dimilikinya sebagai hasil dari prostitusi. Mentraktir korban di 
pusat perbelanjaan sampai meminjami uang agar korban semakin tertarik dengan apa yang dimilikinya.

Dalam kasus T (15) misalnya, ia dijual pacarnya. Pada awalnya ia sangat terpaksa melakukan prostitusi. Namun, pada ahirnya, karena berbagai kemudahan dalam mendapatkan uang sebagai hasil dari praktik tersebut juga kondisi keluarga yang miskin kemudian ia memutuskan untuk masuk ke dunia tersebut dengan mandiri. $\mathrm{T}$ malah mengajak teman perempuannya agar bernasib sama. T yang awalnya menjadi korban kini menjadi pelaku. T mengajak YN (15) teman yang rumahnya bersebelahan agar bisa mendapatkan barang mahal yang seperti yang dia punya. YN setuju dan pada transaksi pertama ia bisa mendapatkan gadjet mahal yang diidamkannya. Mereka berdua bekerjasama memenuhi panggilan permintaan melayani laki-laki hidung belang.

Untuk mendapatkan uang lebih banyak, selain juga ada unsur sakit hati karena merasa terjebak dalam dunia prostitusi, $\mathrm{T}$ dan $\mathrm{YN}$ melakukan modus yang sama yaitu dengan pamer pakaian yang bagus, gadjet yang mahal serta uang yang banyak untuk mengajak teman yang lain masuk ke dalam dunia prostitusi. Ahirnya dua temannya yaitu D (14 tahun) dan W (11 tahun) tertarik dan terjebak dalam dunia prostitusi dengan menunggu panggilan untuk melayani seks laki-laki hidung belang yang berkunjung ke Cianjur.

\section{Mucikari}

Mucikari sebagai pelaku penjualan anak untuk prostitusi ini merupakan kasus yang paling dominan terjadi. Dalam penelitian ini, ditemukan tiga macam mucikari sebagai pelaku yang dibedakan berdasarkan cara kerjanya. Pertama, mucikari sebagai mantan korban yang bekerja secara perorangan untuk merekrut korban tanpa dibantu sindikat perdagangan anak utuk prostitusi. Kedua mucikari yang bekerja merekrut korban dengan bantuan keluarga atau kerabatnya. Ketiga, mucikari yang bekerja dalam sindikat perdagangan anak untuk prostitusi yang terorganisisr untuk merekrut korban.

a. Mucikari yang mantan korban adalah pelaku perdagangan anak untuk prostitusi yang dulunya juga pernah dilacurkan. Oleh karena itu terdapat unsur balas dendam dalam praktik ini yang dilakukan oleh mucikari mantan korban.

$\mathrm{T}$ dan YN sebagaimana dijelaskan sebelumnya masuk sebagai mantan korban yang sekarang bekerja sebagai mucikari. Mereka berdua ini mengajak dua orang anak yaitu $\mathrm{D}$ dan $\mathrm{W}$ ke dalam dunia prostitusi setelah selama dua tahun bekerja menjadi perempuan panggilan. Praktik prostitusi online $\mathrm{T}$ dan $\mathrm{YN}$ pada ahirnya diketahui aparat kepolisian. Kasus ini ditangani dinas sosial kab. Cianjur dan keduanya dimasukan ke dalam penjara untuk direhabilitasi. 
T dan YN yang masih berusia anak sebenarnya terpengaruh oleh Cicih (29 tahun) yang sudah lebih dahulu menjadi mucikari. Cicih adalah salah satu contoh korban perdagangan orang untuk prostitusi. Cicih beralih profesi dari pelacur menjadi mucikari karena merasa dirinya kurang cantik dan mampu menarik hati pelanggan. Selain juga usianya sudah dianggap tua dalam dunia prostitusi. Cicih memiliki mobilitas yang tinggi dari satu tempat prostitusi ke tempat yang lain. Misalnya dari hotel-hotel di wilayah puncak Cianjur, hotel di Bandung, sampai merekrut korban ke luar pulau yaitu Batam. Biasanya Cicih merekrut korban di pedesaan yang padat penduduknya. Iming-iming pekerjaan dan gaji yang tinggi merupakan cara yang biasa digunakan Cicih untuk dapat menjebak korban.

b. Mucikari dan Sindikat Keluarga

Dalam upaya merekrut korban, terkadang mucikari bekerjasama dengan anggota keluarga atau kerabat yang juga bekerja sebagao mucikari di tempat lain. Praktik penjualan orang untuk tujuan prostitusi ini melibatkan sindikat keluarga ini tampaknya efektif karena hubungan antarmucikari lebih bersifat kekeluargaan dengan pembagian hasil yang fleksibel.

Kasus mucikari yang bernama Yadi contohnya. Ia merekrut S (17 tahun), seorang remaja putri yang putus sekolah dengan menawarinya bekerja sebagai penjaga warung di wilayah Pantura. S tertarik menerima tawaran pekerjaan setelah Yadi berhasil meyakinkannya bahwa mencari uang di sana relatif mudah. Yadi merupakan masih saudara Jauh S dan beberapa anggota keluarga juga ada yang bekerja di wilayah Pantura dan hasil dari pekerjaan di sana cukup untuk memenuhi kebutuhan keluarga besar yang miskin.

c. Mucikari sebagai Sindikat terorganisir.

Meskipun sulit dilacak di lapangan, mucikari sebagai bagian sindikat perdagangan orang yang terorganisisr dapat diungkap melalui informasi para korban tentang kronologi pengalaman mereka sejak direkrut, dalam perjalanan hingga ditempatkan. Biasanya mucikari yang tergabung dalam sindikat ini mempunyai tugas masing-masing. Siapa yang bertugas merekrut di daerah asal, memgantar, dan menerima korban di daerah tujuan telah diatur dengan rapi tanpa sepengetahuan korban dengan memanfaatkan jaringan komunikasi telfon dan sosial media.

Dalam Kasus Y (14) misalnya yang dijual D (29) dengan terlebih dahulu menjadi pacar kemudian dijual pada sindikat perdagangan orang. Setelah menjual Y, D pergi begitu saja. Dari penuturan Y pada ahirnya dia berhubungan dengan sindikat perdagangan orang yang menguasai wilayah Cianjur. D ternyata merupakan bagian dari sindikat 
pedagangan orang yang bertugas merekrut korban dengan berbagai cara, diantaranya dengan menjadi pacar atau agen tenaga kerja.

\section{Karakteristik Korban}

Kemiskinan dan dan gaya hidup merupakan karakteristik korban perdagangan anak yang dilacurkan yang paling dominan ditemukan selama penelitian. Hal tersebut tercermin melalui beberapa hal, antara lain, dari kondisi fisik tempat tinggal korban, status pekerjaan orang tuanya dan tingkat pendidikan korban.

1. Tempat tinggal korban

Tempat tinggal korban yang kurang layak merupakan salah satu cerminan miskinnya kehidupan para korban perdagangan anak karena pelacura. Di kabupaten Cianjur, sebagian besar korban yang tinggal dilingkungan yang buruk, menandakan bahwa mereka berasal dari golongan bawah dari seluruh lapisan masyarakat yang ada.

$\mathrm{T}$, seorang korban perdaganyan anak untuk pelacuran contohnya, bersama keluarganya ia tinggal di rumah yang lebih layak dikatakan gubuk karena berdinding kayu yang sudah rapuh. Tidak ada kamar khusus dalam rumah ini sehingga seluruh anggota keluarga yang berjumlah tujuh orang harus tidur di atas tikar di lantai. Rumah mereka juga tidak dilengkapi dengan fasilitas MCK. Untuk listrik pun mereka ambil dari tetangga dengan membayar setiap bulan. Untuk memenuhi kebutuhan air sehari-hari mereka memompa dari MCK umum yang ada di desa.

Gambaran kemiskinan juga tercermin dari rumah tua yang berdinding rapuh atau rumah berdiding papan dan beratap seng yang banyak ditinggali korban perdagangan anak untuk prostitusi beserta keluarganya masing-masing. Tentu saja kondid rumah semacam ini sama sekali tidak memenuhi syarat kesehatan.

2. Status Pekerjaan Orang Tua Korban.

Selain kondisi tempat tinggal, kemiskinan para korban juga dapat diindikasikan pula dari status pekerjaan orang tua mereka yang sebagian besar termasuk subsisten, seperti buruh tani, pedagang keliling, supir di luar kota, tukang bangunan di luar kota, buruh cuci dan TKW (tenaga kerja wanita). Status pekerjaan orang tua korban yang demikian menunjukan bahwa korban berasal darri keluarga relatif kurang mampu secara ekonomi.

Meskipun demikian, ada pula di antara para korban yang berasal dari keluarga yang cukup mampu, namun karena tertimpa masalah keluarga atau masalah perkawinan, korban mencari solusi dengan pergaulan bebas dan ahirnya korban sangat mudah terperangkap ke dunia prostitusi. 
3. Tingkat Pendidikan Korban

Di samping kemiskinan, karakteristik lainnya dari korban perdagangan anak untuk pelacurn adalah ketiadaan akses dengan pendidikan mereka yang rendah. Berdasarka observasi di lapangan, sebagian besar korban perdagangan anak untuk pelacuran adalah lulusan SD, disusul lulusan SMP atau putus sekolah saat SMP. Banyaknya koran yang hanya memiliki tingkat pendidikan rendah ini disebabkan oleh tidak adanya biaya untuk melanjutkan sekolah ke jenjang yang lebih tinggi akibat kondisi ekonomi keluarga mereka yang kurang mampu.

Rendahnya pendidikan, tidak dimilikinya keterampilan khusus dan pengalaman kerja, serta desakan untuk meringankan beban ekonomi keluarga di kalangan korban menjadikan mereka sangat mudah terpedaya oleh sindikat perdagangan anak untuk pelacuran.

4. Gaya Hidup

Gaya hidup sebagian korban yang ingin seperti remaja pada umumnya dengan memiliki barang-barang mahal seperti gadjet, kosmetika, pakaian yang bagus membuat para korban setelah diperdagangkan untuk pelacuran malah meneruskan hal tersebut sebagai profesi setelah putus sekolah. Hal ini berkaitan dengan sosialisasi orientasi kebendaan sebagai ekspresi dari motif berkuasa (power motive). Materialisme adalah faktor yang paling berperan dalam membuat seorang perempuan menjadi pelacur.

\section{Mekanisme Pelacuran}

Berdasarkan hasil penelitian yang telah dilakukan, peneliti menemukan beberapa variasi mekanisme perekrutan prostitusi remaja putri di Cianjur. Adapun variasi mekanisme perekrutan tersebut adalah: Pertama adalah dengan menjanjikan pekerjaan dengan gaji besar, kedua mendekati orang tua calon korban dan ketiga berpura-pura memacari calon korban. Model pendekatan pertama merupakan yang paling dominan ditemukan selama penelitian.

\section{a. Menjanjikan Pekerjaan Dengan Gaji Besar}

Model pendekatan menjanjikan pekerjaan dengan gaji besar sering dimanfaatkan oleh pelaku perdagangan anak untuk pelacuran, baik sebagai mucikari maupun sebaga teman korban. Model ini paling efektif dilakukan terutama terhadap calon korban yang berasal dari keluarga yang kemampuan ekonominya rendah. Biasanya calon korban berhenti sekolah karena tidak ada biaya, menjadi penganggur dan orang tua mendesaknya untuk bekerja agar menambah penghasilan keluarga. Namun karena tidak mempunyai keterampilan khusus dan pengalaman kerja, calon korban dengan mudah termakan janji-janji pelaku perdagangan anak untuk pelacuran. 
Sebagai contoh dalam kasus YN (15) yang berasal dari keluarga kurang mampu yang tinggal di desa dan disuruh berhenti sekolah oleh orang tuanya ketika duduk di kelas IX SMP karena tidak adanya biaya untuk melanjutkan sekolahnya. Kabar ini kemudian diketahui oleh anak dari tetangga sebelah rumah yang yang sedang pulang kampung ke rumah orang tuanya yaitu Y (15). Y sudah bekerja secara mandiri di dunia prostitusi selama setahun dan bekerjasama dengan seorang mucikari bernama Cicih (29). Y sering bepergian ke luar kota apakah di Cianjur, Bandung atau Jakarta bersama Cicih. Ketika Y pulang kampung dia mendengar temannya YN akan berhenti sekolah karena tidak ada biaya lagi. Kemudian Y bercerita kepada Cicih tentang masalah yang dihadapi temannya. Cicih yang sudah berpengalaman sebagai mucikari mengajak $\mathrm{Y}$ merayu YN dengan sejumlah uang dan tawaran pekerjaan dengan gaji yang besar. Y ahirnya menawari YN pekerjaan dan menjanjikan bahwa YN akan seperti dirinya memiliki segala fasilitas yang diinginkan remaja seusianya. Selain juga memberikan sejumlah uang dan penawaran itu diterima dengan senang hati oleh tetangga sebelah rumahnya tersebut. Orang tua YN yang memang secara ekonomi miskin, merasa terbantu dan senang anaknya diajak bekerja oleh temannya. Y dan YN melakukan hal yang sama pada $\mathrm{D}$ dan $\mathrm{W}$ yang juga ditawari pekerjaan dengan gaji besar.

Y dan YN ahirnya tinggal di kostan di kota Cianjur dengan bantuan Cicih. Di sini mereka bekerja sebagai perempuan panggilan yang diatur oleh jaringannya Cicih. Cicih tidak mengenalkan Y dan YN dengan sindikat yang ia ikuti. Y dan YN hanya menerima panggilan dari beberapa jejaring sosial yang dikelola Cicih. Cicih cukup selektif memilih orang yang akan memesan dua anak yang direkrutnya ini. Hubungan mereka seperti saudara. Y dan YN merasa bahwa Cicih adalah penolong yang diutusNya untuk menyelamatkan mereka dari kemiskinan.

\section{b. Mendekati Orang Tua Calon Korban}

Model pendekatan selanjutnya oleh pelaku perdagangan anak untuk pelacuran dalam rangka merekrut calon korban adalah dengan mendekati orang tuanya. Model pendekatan ini paling efektif dilakukane terutama dengan berpura pura meminjami atau bahkan memberikan uang kepada orang tua korban yang tidak mampu secara ekonomi. Karena orang tua terlanjur memiliki hutang kepada pelaku perdagangan anak untuk pelacuran dan tidak bisa mengembalikan hutngnya, maka mereka pun terpaksa menyerahkan anaknya kepada pelaku.

$\mathrm{S}$ adalah salah satu contoh korban yang terpaksa diserahkan karena orang tuanya tidak mampu melunasi hutang. Yadi sebagai saudara jauh sering meminjami orang tua $\mathrm{S}$ uang untuk melunasi utang pada renternir dan mencukupi biaya hidup. Saat hutangnya pada yadi sudah sebesar Rp. 4.000.000, Yadi meminta orang tua $S$ mengizinkan ia membawa $S$ untuk bekerja di daerah Pantura untuk membayar hutang. Orang tua S sebenarnya 
mengetahui pekerjaan apa yang ditawarkan Yadi, karena ada beberapa anggota keluarga yang juga bekerja di sana. Kemiskinan dan ingin seperti anggota keluarga yang lain yang dianggap sukses, orang tua $\mathrm{S}$, tega mengizinkan anakknya bekerja sebagai pelacur. Keluarga besar ini memang menjadi sorotan dan gunjingan di desa tersebut, namun karena tempatnya jauh maka masyarakat dan aparat desa tidak bisa melakukan apa-apa.

\section{c. Memacari calon korban}

Berpura pura menjadi pacar calon korban merupakaan model pendekatan lain yang kadang digunakan oleh pelaku perdagangan anak untuk pelacuran dalam rangka merekrut calon korbannya dan tampaknya ini efekti untuk dapat menjerat korban. Hal ini terjadi dalam kasus T yang mengharapkan pacarnya akan menjadi tumpuan masa depannya, tetapi justru menjualnya dan menjerumuskannya ke dalam pekerjaan yang dianggapnya paling hina dan memalukan bagi dirinya dan keluarganya.

\section{Ketahanan Keluarga Remaja Putri Yang Menjadi Korban.}

Keluarga merupakan arena utama dan pertama untuk melakukan interaksi sosial dan mengenal perilaku-perilaku yang dilakukan oleh orang lain. Juga keluarga sebagai tonggak awal dalam pengenalan budaya-budaya masyarakat dalam mana anggota keluarga belajar tentang pribadi dan sifat orang lain di luar dirinya. Karena itu keluarga merupakan wadah yang memiliki arti penting dalam pembentukan karakter, hubungan kekerabatan, sosial dan kreativitas para anggotanya. Karena itu sangat menarik untuk dikaji urgensitas keluarga ini dalam berbagai dimensinya baik oleh para ilmuwan maupun para praktisi (Ulfiah, 2016).

Salah satu ilmuwan pertama yang mengkaji keluarga adalah George Murdock. Dalam bukunya Social Structure, Murdock menguraikan bahwa keluarga merupakan kelompok sosial yang memiliki karakteristik tinggal bersama, terdapat kerja sama ekonomi, dan terjadi proses reproduksi (Lestari, 2012).

Menurut Bossard \& Ball dalam Notosoedirdjo dan Latipun(2001) memberikan batasan tentang keluarga dari aspek kedekatan hubungan satu sama lain dengan mengatakan bahwa, keluarga sebagai lingkungan sosial yang sangat dekat hubungannya dengan seseorang. Pada keluarga itu seseorang dibesarkan, bertempat tinggal, berinteraksi satu dengan yang lain, dibentuknya nilai-nilai, pola pemikiran, dan kebiasaannya. Keluarga juga berfungsi sebagai seleksi segenap budaya luar, dan dimensi hubungan anak dengan lingkungannya. Oleh karena itu, keluarga merupakan lembaga sosial yang mempunyai multi fungsi, dalam membina dan mengembangkan interaksi antar anggota keluarga. Keluarga merupakan sarana pengasuhan bagi anak-anak untuk belajar hal-hal yang menyangkut masalah norma agama, nilai dan adat istiadat yang berlaku dalam masyarakat. Pengasuhan dapat didefinisikan sebagai pola perilaku yang diterapkan orangtua 
terhadap anak-anaknya, melalui interaksi langsung atau tidak langsung, baik yang sifatnya memberi dukungan maupun yang bersifat menghambat anak, dalam segala aktifitas eksplorasi dan komitmen demi mencapai status identitas dirinya (Ulfiah, 2016). Sebagaiamana sudah diuraikan pada bab sebelumnya, Ketahanan keluarga (family strength atau family resilience) merupakan kondisi kecukupan dan kesinambungan akses terhadap pendapatan dan sumber daya untuk memenuhi berbagai kebutuhan dasar antara lain: pangan, air bersih, pelayanan kesehatan, kesempatan pendidikan, perumahan, waktu untuk berpartisipasi di masyarakat, dan integrarsi sosial (Frankenberger, 1998). Ketahanan keluarga juga mengandung maksud sebagai kemampuan keluarga untuk mengembangkan dirinya untuk hidup secara harmonis, sejahtera dan bahagia lahir dan batin. Sunarti (2001) menyebutkan bahwa ketahanan keluarga mencakup kemampuan keluarga untuk mengelola sumber daya dan masalah untuk mencapai kesejahteraan.

Menurut UU Nomor 10 Tahun 1992 (Pasal 1 Ayat 15) ketahan keluarga didefinisikan sebagai kondisi dinamik suatu keluarga yang memiliki keuletan dan ketangguhan serta mengandung kemampuan fisikmaterial dan psikis mental spiritual guna hidup mandiri dan mengembangkan diri dan keluarganya untuk hidup harmonis dalam meningkatkan kesejahteraan lahir dan batin.

\section{Pendekatan sistem ketahanan keluarga.}

1. Komponen input. Komponen ini meliputi dari sumber daya keluarga termasuk nilai dan tujuan yang menjadi dasar keluarga. sumberdaya keluarga memiliki makna sebagai sumber dari kekuatan, potensi dan kemampuan keluarga untuk mencapai suatu manfaat atau tujuan. Sumber daya keluarga merupakan apa yang dimiliki dan dikuasai individu dalam keluarga baik bersifat fisik-material maupun non fisik yang dapat diukur maupun tidak dapat diukur, sumber daya ekonomi manusia, maupun lingkungan di sekitar keluarga untuk mencapai tujuan keluarga itu sendiri. Contoh: keahlian yang dimiliki anggota keluarga, lingkungan yang memadai (lingkungan yang kondusif).

2. Komponen proses. Komponen ini merupakan proses keluarga mengelola sumber daya keluarga, masalah yang dihadapi dan penanggulangan masalah keluarga. Manajemen sumberdaya keluarga merupakan pengelolaan keluarga atas sumberdaya keluarga (baik yang dimiliki atau yang bisa diakses keluarga) seperti bagaimana mengelola waktu dalam keluarga, pembagian tugas dalam keluarga. Komponen proses merupakan bagaimana keluarga dapat mengatur masalah yang dihadapi sehingga tidak mengganggu kestabilan keluarga.

3. Komponen output. Output dari ketahanan keluarga adalah kesejahteraan keluarga, yaitu terpenuhinya kebutuhan fisik dan non 
fisik keluarga, kebutuhan dasar dan perkembangan keluarga (Euis Sunarti, 2017).

\section{Kesejahteraan keluarga.}

Kesejahteraan keluarga adalah terciptanya suatu keadaan yang harmonis dan terpenuhinya kebutuhan jasmani serta sosial bagi anggota keluarga, tanpa mengalami hambatan-hambatan yang serius di dalam lingkungan keluarga, dan dalam menghadapi masalah-masalah keluarga akan mudah untuk di atasi secara bersama oleh anggota keluarga sehingga standar kehidupan keluarga dapat terwujud (UU Nomor 52 Tahun 2009). Kesejahteraan keluarga merupakan tingkat pemenuhan kebutuhan dasar dan kebutuhan perkembangan keluarga.

Kesejahteraan keluarga dapat diukur dengan dua cara yaitu kesejahteraan objektif dan subjektif, sedangkan lingkupnya dapat dibagi menjadi kesejahteraan fisik, kesejahteraan sosial, dan kesejahteraan psikologis. Apabila keluarga telah memiliki nilai, tujuan yang jelas dan mampu mengelola sumberdaya yang dimiliki dengan optimal maka pada akhirnya akan mencapai kesejahteraan secara fisik, yaitu telah mampu memenuhi kebutuhan dasar (pangan dan papan), sosial (memiliki hubungan yang baik dan sehat dengan anggota keluarga maupun masyarakat secara luas), psikologis (memiliki kepuasan terhadap pencapaian kehidupannya).

Kesejahteraan dapat dinilai baik bedasarkn pada, Kesejahteraan objektif, di mana tingkat pemenuhan kebutuhan dasar dan perkembangan secara objektif, yaitu mengacu kepada standar normatif dan ideal, maupun Kesejahteraan subjektif, yang merupakan kepuasan terhadap tingkat pemenuhan kesejahteraan yang ditunjukkan secara objektif.

\section{Mencapai ketahanan keluarga}

1. Kesiapan pasangan sebelum membangun keluarga.

a. Setidaknya salah satu dari pasangan memiliki keterampilan kerja untuk memperoleh sumberdaya ekonomi bagi kehidupan keluarga yang akan dibangun.

b. Kedua pasangan memiliki sumberdaya manusia berkualitas sehingga mampu mengelola sumberdaya dan ekosistem keluarga.

c. Kedua pasangan memiliki kematangan psikologis (usia memadai) dan kepribadian untuk memenuhi fungsi, peran, dan tugas keluarga, serta mampu berkomitmen untuk melaksanakan keluarga berencana.

d. Pasangan berkomitmen untuk membangun keluarga, saling berbagi dan memberi cinta dan kassih sayang, melindungi, saling memenuhi hak dan kewajiban, loyalitas, dan kesediaan berkorban. Pasangan telah memasuki usia yang matang untuk berkeluarga. 
2. Pada saat berkeluarga.

a. Menjalankan, memelihara, dan menguatkan nilai dan tujuan keluarga.

b. Menjalankan fungsi, peran, dan tugas keluarga.

c. Mengelola sumberdaya keluarga dengan baik.

d. Mengelola perubahan, sumber stress, dan stress dengan cerdas.

e. Mencegah atau mengelola krisis.

f. Membangun interaksi keluarga yang optimal.

g. Memenuhi tugas perkembangan keluarga sepanjang kehidupan keluarga.

h. Bertransaki secara positif dengan lingkungan sosial dan lingkungan alam. (Euis Sunarti, 2017).

\section{Dimensi Legalitas dan Keutuhan Keluarga}

Legalitas perkawinan merupakan salah satu landasan penting bagi keluarga untuk membentuk sebuah keluarga harmonis yang sejahtera lahir dan batin. Perkawinan yang tidak sah menurut hukum yang berlaku akan menjadi hambatan dalam mencapai kesejahteraan dan ketahanan keluarga karena mengandung resiko tidak terpenuhinya hak-hak istri dan anak. Bukti perkawinan yang sah berupa dokumen pencatatan perkawinan yang dikeluarkan oleh instansi yang berwenang. Bagi penduduk yang beragama Islam maka pencatatan perkawinan dilakukan oleh Pegawai Pencatat Nikah dari Kantor Urusan Agama (KUA) atau oleh pegawai yang ditunjuk oleh Menteri Agama. Sebaliknya, bagi mereka yang melangsungkan perkawinan menurut agama dan kepercayaan selain agama Islam maka dilakukan oleh Pegawai Pencatat Perkawinan pada Kantor Dinas Kependudukan dan Pencatatan Sipil (Peraturan Pemerintah Nomor 9 Tahun 1975).

Keluarga korban pedagangan anak untuk pelacuran dalam penelitian ini sebagian besar orang tuanya tidak memiliki surat nikah. Sebagai warga desa pernikahan yang dilakukan hanya sah secara agama dan tidak dicatatkan.

\section{Dimensi Ketahanan Fisik dan Ekonomi}

Ketahanan fisik dan ekonomi keluarga remaja putri di cianjur ini lebih pada keluarga yang kemampuan ekonominya menengah kebawah hal ini jika dilihat dari komponen ketahanan keluarga, keluarga ini belum memiliki ketahanan yang berkaitan dengan kemampuan ekonomi keluarga yang terpenuhi kebutuhannya, yaitu kemmapuan anggota keluarga dalam memperoleh sumberdaya ekonomi dari luar sistem keluarga untuk memenuhi kebutuhan dasar seperti pengan, sangdang, perumahan, pendidikan dan kesehatan. Keluarga dikatakan telah memiliki ketahanan fisik apabila memiliki pendapatan per kapita yang melebihi dari kebutuhan fisik minimum (sandang, pangan, papan) dan atau lebih dari satu orang keluarga bekerja dan memperoleh sumber daya ekonomi melebihi 
kebutuhan fisik dan kebutuuhan perkembangan seluruh anggota keluarga. kebutuhan dasar kelurga meliputi:

a. Kebutuhan pangan (makan dan minum) sesuadi dengan kebutuhan masing-masing anggota keluarga.

b. Kebutuhan sandang yaitu setiap anggota keluarga memiliki pakaian ganti lengkap (yang berbeda untuk aktivitas dan fungsi tertentu), perlengkapan ibadah, dan lain-lain.

c. Kebutuhan pendidikan yaitu mampu menyekolahkan anak usia sekolah, dan memenuhi kebutuhan seperti seragam, tas, sepatu, buku tulis, mainan yang melatih/menunjang pengetahuan, buku bacaan, pembayaran SPP sekolah dan uang saki anak.

d. Kebutuhan kesehatan yaitu mampu memberikan sarana agar keluarga senantiasa sehat dan bersih.

e. Kebutuhan papan yaitu rumah tempat berlindung dan seluruh isi kelengkapannya.

\section{Ketahanan Psikologi}

Keluarga merupakan lingkungan pertama dan utama bagi anak untuk membentuk kepribadian dan mencapai tugas-tugas perkembangannya. Oleh karena itu, keluarga menjadi faktor yang terpenting bagi pembentukan sikap dan prilaku anak baik dalam segi kepribadian, sosial maupun emosional anak. Keluarga memiliki peran yang sangat penting dalam upaya mengembangkan kepribadian anak. Perawatan orangtua yang penuh kasih sayang dan pendidikan tentang nilai-nilai kehidupan, baik agama maupun sosial budaya yang diberikan merupakan faktor yang sangat mendukung untuk mempersiapkan anak menjadi pribadi dan anggota masyarakat yang baik (Ulfiah, 2016).

Peran keluarga menggambarkan seperangkat perilaku inter personal, sifat kegiatan yang berhubungan dengan individu dalam posisi dan situasi tertentu. Peran individu dalam keluarga didasari oleh harapan dan pola perilaku dari keluarga, kelompok dan masyarakat.

Berdasarkan data yang diperoleh kemampuan keluarga untuk mengelola emosi masih perlu diikembangkan sehingga menghasilkan konsep diri yang positif dan kepuasan terhadap pemenuhan kebutuhan dan pencapaian tugas perkembangan keluarga. kemampuan mengelola emosi dan konsep diri yang baik menjadi kunci dalam menghadapi masalahmasalah keluarga yang bersifat non fisik (masalah yang tidak berkaitan dengan materi seperti masalah kesalah pahaman, konflik suami dan istri, dan sebagainya). Keluarga dikatakan memiliki ketahanan psikologis apabila anggota keluarga memiliki konsep diri dan emosi yang positif. Syarat utama untuk tercapainya ketahanan psikologis adalah kepribadian yang matang dan kecerdasan emosi pasangan suami dan istri yang akan berdampak pada bagaimana pengasuhan yang mereka (orang tua) berikan kepada anaknya baik pada usia anak dan remaja pada subyek penelitian ini. 
Menyoal anak dan remaja ini pasti berhubungan dengan peer groupnya atau adanya peran teman sebaya dan hal ini berkaitan dengan tugas perkembangannya.Salahsatu tugas perkembangan remaja adalah berhubungan dengan penyesuaian sosial terhadap lingkungan yang baru. Untuk mencapai tujuan pola sosialisasi tersebut, remaja harus melakukan penyesuaian diri dengan meningkatkan pengaruh kelompok sebaya (peer group), perubahan dalam perilaku sosial, pengelompokan sosial yang baru, nilai-nilai baru dalam seleksi persahabatan, nilai-nilai baru dalam dukungan dan penolakan sosial, dan nilai-nilai baru dalam kepemimpinan.

Identitas versus kebimbangan identitas (identity versus identity confusion) merupakan tahap perkembangan Erikson yang kelima yang terjadi pada saat individu berada pada masa remaja. Pada tahap ini, remaja berusaha untuk menemukan siapakah mereka sebenarnya, apa saja yang ada dalam diri mereka, dan arah mereka dalam menjalani hidup. Remaja menjalani berbagai peran dalam kehidupan. "Ketika remaja mengeksplorasi dan mencari identitas budayanya, remaja seringkali bereksperimen dengan peran-peran berbeda. Remaja yang berhasil menghadapi dengan identitasidentitas yang saling bertentangan akan mendapatkan pemikiran yang baru dan dapat diterima mengenai dirinya. Remaja yang tidak berhasil menyelesaikan krisis identitasnya, akan mengalami yang disebut Erikson sebagai identity confusion (kebimbangan akan identitasnya). Akibatnya, remaja akan menarik diri, mengisolasi diri dari teman sebaya dan keluarga, atau meleburkan diri dengan dunia teman sebayanya dan kehilangan identitas dirinya". (Santrock, 1996).

\section{Ketahanan Sosial Budaya}

Merujuk hasil observasi dan wawncara, baik dengan responden maupun aparat desa dan pihak terkait, dapat diketahui beberapa bukti terkait ketahanan sosial yang dimiliki dalam keluarga responden. Responden merupakan keluarga yang memiliki lingkungan agama yang baik, bahkan ada salah satu responden yang orag tuanya adalah tokoh agama masyarakat setempat, namun ketika hal ini terjadi menunjukkan ketidak mampuan mendidik dalam penerapan nilai agama, pemeliharaan ikatan dan komitmen, komunikasi efektif, pembagian dan penerimaan peran, penetapan tujuan serta dorongan untuk maju yang akan menjadi kekuatan dalam menghadapi masalah keluarga serta tidak memiliki hubungan sosial yang positif.

Ketahanan sosial terdiri atas sumber daya non fisik, mekanisme penanggulangan masalah yang baik, berorientasi terhadap nilai-nilai agama, efektif dalam berkomunikasi, senantiasa memelihara dan meningkatkan komitmen keluarga, memelihara hubungan sosial, serta memiliki penanggulangan krisis atau masalah.

Jika melihat dari sebuah harapan akan ketahanan sosial yang efektif, tentu ntuk mencapainya diperlukan kerja keras dan kerja cerdas meski 
dihadapkan pada tantangan internal dan sosial, kendala pembiayaan dan kelatahan iklim demokrasi yang seakan tak terbendung, latah melakukan demonstrasi menuntut hak yang seakan melupakan kewajiban yang seolah menjadi kelatahan sosial. Tuntutan demokrasi yang diartikan sebagai kebebasan tanpa aturan, tuntutan otonomi sebagai kemandirian tanpa kerangka acuan yang mempersatukan seluruh komponen bangsa, hak asasi manusia yang terkadang mendahulukan hak dari pada kewajiban. Pada akhirnya berkembang kearah berlakunya hukum rimba yang memicu kesukubangsaan (ethnicity). Kerancuan ini menyebabkan orang frustasi dan cenderung melupakan perasaan tanpa kendali dalam bentuk "amuk massa atau amuk sosial".

Selanjutnya, pada konteks pemahaman agama (Islam) sudah jelas bahwa pendidikan anak dimulai dari rumah (orangtua) dan pendidikan orangtua tersebut dapat berpengaruh pada perilaku anak. Terkait hal ini dalam sebuah Hadits yang diriwayatkan oleh Bukhori Muslim yang artinya. "Setiap anak dilahirkan dalam keadaan fitrah, maka orang tuanyalah yang akan menjadikan anak tersebut, apakah yahudi, nashroni atau majusi". Demikian juga dalam Al-Qur'an Surah An-Nisa ayat 9 Allah berfirman, yang artinya, "Dan hendaklah takut kepada Allah orang-orang yang seandainya meninggalkan dibelakang mereka anak-anak yang lemah, yang mereka khawatir terhadap (kesejahteraan) mereka. Oleh sebab itu hendaklah mereka bertakwa kepada Allah dan hendaklah mereka mengucapkan perkataan yang benar".

Berhadapan dengan berbagai masalah dan tantangan di atas, lembaga pendidikan (keluarga) tetap memikul peran multi dimensional. Berbeda dengan peran pendidikan pada negara-negara maju, yang pada dasarnya lebih terbatas pada transfer ilmu pengetahuan, peranan pendidikan di Indonesia memikul beban lebih berat, karena pendidikan berperan bukan hanya sebagai sarana transfer ilmu pengetahuan saja namun lebih luas lagi yakni sebagai pembudayaan (enkulturisasi) sebagai sesuatu yang urgen. Dan pembudayaan itu terkait dengan pembentukan karakter dan watak (nation and character building), yang pada gilirannya sangat menentukan corak dan kelangsungan pembangunan bangsa (nation building)untuk menuju rekonstruksi negara dan bangsa yang lebih maju dan beradab.

Oleh karena itu, reformasi pendidikan sangat mutlak diperlukan untuk membangun karakter atau watak suatu bangsa, bahkan merupakan kebutuhan mendesak. Reformasi kehidupan nasional secara singkat, pada intinya bertujuan untuk membangun Indonesia yang lebih genuinely dan authentically demokratis dan berkeadaban, sehingga betul-betul menjadi Indonesia baru yang madani, yang bersatu padu (integrated) menyatu membahu. Di samping itu, peran pendidikan nasional dengan berbagai jenjang dan jalurnya merupakan sarana paling strategis dalam mengasuh, membesarkan dan mengembangkan warga negara yang demokratis dengan memiliki keadaban (civility) kemampuan, keterampilan, etos dan motivasi 
serta berpartisipasi aktif, sebagai refleksitas ciri dan karakter bangsa Indonesia yang mengedepankan tatanan masyarakat madani. Kita tidak berharap, tidak terjadi destruktifitas yang menimbulkan kekerasan yang meregenerasi seperti halnya yang terjadi di beberapa perguruan tinggi di Indonesia, bahkan fenomena bullying pada sekolah/madrasah di Bandung dan kota-kota besar di Indonesia. Kekerasan fisik yang mengorbankan nyawa dan harta benda tersebut, sangat jelas terkait pula dengan masih bertahannya "kekerasan struktural" (structural violence) pada tingkat tertentu. Akibatnya, perdamaian hati secara menyeluruh belum tercapai secara optimal.

Sebagai illustrasi dikemukakan hasil penelitian Peneliti (2004) tentang; Hubungan Antara Gaya Pengasuhan Orang Tua dengan Pencapaian Status Identitas, dapat diketahui bahwa memiliki hubungan signifikan. Demikian juga penelitian yang dilakukan pada tahun 2010, pada topik Hubungan Antara Perilaku Bullying dengan Komitmen Beragama pada Siswa SMA di Kota Bandung menunjukkan, selain faktor diri (siswa) komitmen beragama juga dapat dibangun melalui pendidikan keluarga. Terkait pengaruh keluarga juga penelitian penulis pada tahun 2012 tentang Konseling Rasional Emotif Perilaku bagi Pelaku Bullying di Madrasah dapat diketahui bahwa, perilaku bullying juga dapat dipengaruhi oleh faktor gaya pengasuhan orangtua. Oleh karena itu, mempelajari psikologi keluarga adalah merupakan kebutuhan yang mendasar, mengingat perilaku individu dalam berinteraksi dengan lingkungan pertama kali dengan lingkungan keluarga, bahkan pendidikan yang pertama dan utama juga adalah pendidikan dalam keluarga.

Chuang (2005) dalam Ulfiah (2016) menyebutkan bahwa kesejahteraan dan keharmonisan keluarga dapat dilihat dari harapan peran dan saling melengkapi antar anggota keluarga sehingga menimbulkan efek positif dalam pola interaksi dalam keluarga tersebut.Hal tersebut dilakukan sebelum, selama dan setelah pernikahan. Apabila hal itu terpenuhi, maka permasalahan yang timbul tidak akan mempengaruhi keharmonisan keluarga. Demikian kehidupan dalam keluarga harmonis yang didambakan oleh setiap pasangan akan mudah terlaksana.

Kendala yang akan dihadapi seperti konflik komunikasi, ekonomi, dan kebutuhan psikologis yang akan mengakibatkan permasalahan. Penelitian yang dilakukan pada Marsinah (2003) yaitu suatu perkawinan yang berawal dari saling menyembunyikan sifat-sifat diri akan berakibat timbulnya permasalahan dari ekonomi, komunikasi, dan kebutuhan biologis. Kendala dalam berkomunikasi dapat mengakibatkan kehidupan pernikahan dalam keluarga menjadi tidak harmonis, seperti hubungan antara orangtua dan anak tidak baik, dan percekcokan antara suami dan istri (Kertamuda, 2009).

Melihat fenomena di atas maka, psikologi dalam keluarga sangat penting artinya bagi komunitas masyarakat terkecil dimaksud. Hal ini dapat 
dimengerti sebab, keluarga merupakan kelompok sosial yang terkecil dalam masyarakat yang membangun sebuah bangsa. Keluarga mempunyai andil yang besar dalam keberhasilan membangun suatu bangsa. Bangsa yang besar itu dapat tercermin dari masing-masing keluarganya. Hal tersebut berkaitan dengan peran keluarga sebagai tempat untuk mencurahkan segala kasih sayang antara orangtua terhadap anaknya ataupun sebaliknya. Keluarga juga akan memberikan kehangatan, kedekatan, serta rasa aman bagi anak dan anggota keluarga lainnya.

Undang-Undang Nomor 1 Tahun 1974 melihat bahwa, perkawinan adalah ikatan lahir bathin antara seorang pria dan seorang wanita sebagai suami istri dengan tujuan membentuk keluarga atau rumah tangga yang bahagia dan kekal berdasarkan Ketuhanan Yang Maha Esa. Karena itu, Kertamuda (2009) melihat bahwa, pernikahan merupakan suatu penerimaan hubungan pasangan yang diharapkan dapat stabil dan bertahan.

Berbagai kasus-kasus yang dikemukakan di atas, terdapat beragam permasalahan yang terjadi ketika keluarga menjadi tidak harmonis. Padahal dapat dijumpai saat berlangsungnya pernikahan pada pasangan Islam bahwa akan bercita-cita untuk menjadi keluarga sakinah wamaddah warahmah dan tujuan inilah yang dapat menciptakan sebuah ketahanan keluarga.

Keluarga dikatakan memiliki tingkat ketahanan keluarga yang tinggi apabila memenuhi beberapa aspek yaitu: (1) Ketahanan fisik yaitu terpenuhinya kebutuhan pangan, sandang, perumahan, pendidikan dan kesehatan; (2) Ketahanan sosial yaitu berorientasi pada nilai agama, komunikasi yang efektif, dan komitmen keluarga tinggi; (3) Ketahanan psikologis meliputi kemampuan penanggulangan masalah nonfisik, pengendalian emosi secara positif, konsep diri positif, dan kepedulian suami terhadap istri yang semuanya itu berkaitan dengan ketercapaian kesejahteraan dalam keluarga.

Menciptakan keluarga sejahtera itu tidak terlepas dari usaha anggota keluarga untuk mengembangkan keluarga yang berkualitas yang diarahkan pada terwujudnya kualitas keluarga bercirikan kemandirian keluarga dan ketahanan keluarga. Pengembangan keluarga yang berkualitas dan sejahtera ini ditunjukan agar keluarga dapat memenuhi kebutuhan spiritual dan material sehingga dapat menjelaskan fungsi keluarga secara optimal.

\section{KESIMPULAN DAN SARAN}

\section{Kesimpulan}

Berdasarkan hasil penelitian dan pembahasan, maka dapat disimpulkan bahwa; Kabupaten Cianjur memiliki Visi dan Misi pada tahun 2016-2021 yang ingin dicapai dalam masa jabatan selama 5 (lima) tahun. Visi Kabupaten Cianjur adalah Cianjur lebih maju dan agamis. Hal 
ini berlandaskan nilai-nilai akhlakul karimah sebagai penunjang utama bagi keberhasilan pembangunan di berbagai bidang. Dengan potensi wilayahnya Cianjur lebih berpotensi sebagai daerah yang agamis, namun persoalan masyarakat atau penyakit masyarakat tidak bisa dihidari seperti halnya dengan adanya prostitusi yang tentunya berkaitan dengan faktor-faktor yang melatar belakanginya.

Prostitusi remaja putri di Cianjur dilihat dari karakteristik tempat prostitusi, karakteristik pelaku dan korban serta mekanisme prostitusi yang terjadi, dalam penelitian ini, ditemukan ada empat macam pelaku perdagangan anak untuk prostitusi, yaitu pacar, teman, dan mucikari. Bagi sebagian besar pelaku yang terlibat dalam perdagangan anak untuk prostitusi ini, keterlibatan mereka merupakan pekerjaan sampingan. Namun ada pula beberapa orang di antaranya yang menjadikan pekerjaan tetap. Para pelaku tidak mempunyai keterikatan formal apa pun dalam sindikat perdagangan anak dengan tujuan prostitusi ini.

Kemiskinan dan dan gaya hidup merupakan karakteristik korban perdagangan anak yang dilacurkan yang paling dominan ditemukan selama penelitian. Hal tersebut tercermin melalui beberapa hal, antara lain, dari kondisi fisik tempat tinggal korban, status pekerjaan orang tuanya dan tingkat pendidikan korban.

Adapun ketahanan keluarga remaja putri yang menjadi korban, bedasarkan observasi dan wawancara menunjukkan adanya ketahanan keluarga yang lemah, seperti halnya ketahanan agamanya fisik ekonominya, psikologisya, maupun sosial budayanya.

\section{DAFTAR PUSTAKA}

Abu Ahmadi. 1991. Psikologi Belajar. Jakarta. PT Rineka Cipta.

Agung, Bambang, 1996. "Michel Foucault tentang Kekuasan", Majalah Driyakara, tahun XXI no 2.

Anwar, 1999. Desentralisasi Spasial melalui Pembangunan Agropolitan, Dengan Mereplikasi Kota-kota Menengah Kecil di Wilayah Perdesaan. Buletin Tata Ruang .

Arivia, Gadis. 2003. Filsafat Berperspektif Feminis. Jakarta: Yayasan Jurnal Perempuan.

Dalyono, M. 1997. Psikologi Pendidikan. Jakarta: PT.Rineka Cipta

Departemen Pendidikan dan Kebudayaan, 1999. Kamus Besar Bahasa Indonesia, Jakarta: Balai Pustaka,

Boeang, Kondrad Kebung. 1997. Michel Foucault Parhesia dan Persoalan Mengenai Etika, Jakarta: Penerbit Obor.

Bungin, Burhan. 2010. Analisis Data Penelitian Kualitatif. Jakarta : Raja Grafindo Persada. 
Creswell, John W. 2010. Research Design:Pendekatak Kualitatif, Kuantitatif dan Mixed, Yogyakarta: Pustaka Pelajar.

Euis Sunarti, 2017. Worshop Diagnostik Ketahanan Keluarga, Bogor.

Fathonah, Rini. 2015.Analisis terhadap Faktor Penyebab Prostitusi Pada Anak dalam Jurnal Ilmu Hukum. Fiat Justitia Volume 9 No 2 April- Juni.

Goodman, Douglas J \& George Ritzer. 2005. Terjemahan oleh Alimandan, Teori Sosiologi Modern, Jakarta: PT.Gramedia, Edisi 6.

Haryatmoko. 2002."Kekuasaan Melahirkan Anti-Kekuasaan ; Menelanjangi Mekanisme dan Teknik Kekuasaan Bersama Foucault", Makalah Kuliah Umum Filsafat Sosial 25 Maret 2013 di Jurusan Aqidah Filsafat Fakultas Ushuluddin UIN Bandung, 5. Artikel ini pernah dimuat di Majalah BASIS no: 01-02 Tahun ke 51.

Holzner, Brigitte dan R. Saptari. "Research Appoach" Dalam Brigitte Holzner, Gender Methodology in Agricultural Project, (Netherland: Departement of Gender Studies in Agricultural, Weagning University)

Hurlock. Elizabeth B. 1980. Psikologi Perkembangan Suatu Pendekatan Sepanjang Rentang Kehidupan. Edisi Ke-Lima. Alih Bahasa Istiwidayanti dan Soedjarwo. Jakarta : Erlangga..

http://www.beritasatu.com/nasional/301396-modus-perdagangan-orang-makinberagam.html). diakses 19 April 2017 pukul 22.25 WIB

http://www.harianindo.com/2016/06/05/113968/kasus-prostitusi-online-dicianjur-akhirnya-terbongkar/) diakses 19 April 2017 pukul 22.25 WIB

http://www.kpai.go.id/berita/kpai-catat-ratusan-anak-diperjualbelikan-tangkappenjual-bayi-rp25-juta-lewat-online 1

http://digilib.unila.ac.id/291/9/BAB\%20II.pdf

Irwansyah, Lutfi. 2016. Kemiskinan, Keluarga dan Prostitusi Remaja, Yogyakarta: UMM.

Kendal, Gavin dan Gary Wickham. 1999. Using Foucault Methods, London, Thousand Oaks New Delhi: SAGE Publication.

Kompas 25 Agustus 2015

Kartono, Kartini. 2011. Patologi Sosial 2 Kenakalan Remaja cetakan ke-10. Jakarta: PT. Raja Grapindo Persada.

Kertamuda, F dan Herdiansyah H. 2009. Pengaruh Strategi Coping terhadap Penyesuaian Diri Mahasiswa Baru. Jurnal Universitas Paramadina. Vol, 6.No.1 . 11-23.

Kuhn, Thomas S. 1970. The Structure of Scientific Revolution, Herndon: The University of Chicago Press.

Latipun. 2001. Psikologi Konseling, Malang: UMM Press.

Lestari, S. 2012. Psikologi Keluarga.Jakarta: Kencana.

Monks, F. J, Knoers, A. M. P, and Haditono, S. R. 1999. Psikologi Perkembangan, 1999. 
Muflichah, Siti dan Rahadi Wasi Bintoro. 2009. Trafficking: Suatu Studi tentang Perdagangan Perempuan dari Aspek Sosial, Budaya dan Ekonomi di Kabupaten Banyumas, Jurnal Dinamika Hukum Vol 9 No 1 Januari

Mulyanto. Melacur Demi Hidup, 2000 ; Fenomena Perdagangan Anak Perempuan di Palembang, Yogyakarta: PSKK UGM dan Ford Fondation.

Munti, Ratna Batara. 2005. Demokrasi Keintiman; Seksualitas di Era Global, Yogjakarta: LKiS.

Poerwandari, Kristi. 2005. Pendekatan Kualitatif untuk Penelitian Perilaku Manusia. Ed. Ke-3, Depok: LPSP3 FPUI.

Pramono, Made. 2009. "Melacak Basis Epistimologi Antonio Gramsci" Listiyono Santoso, dkk, Epistimologi Kiri, Jogjakarta: Ar-Ruzz Media Group, Cet. K3-7.

Reinharz, Shulamit. 2005. Metode-Metode Feminis dalam Penelitian Sosial, terjemahan oleh Lisabona Rahman, ed. Sita Aripurnami, Jakarta: Women Research Institute.

Papalia, D. E. 2008. Human Development. Jakarta : Kencana Prenada Media Group.

Ramayulis. 2002. Psikologi Agama. Bandung: Kalam Mulia.

Rismayanti, Yanuar Farida. Perdagangan Anak Perempuan yang dilacurkan dalam Prociding Child Poverty And Social Protection Conference Jakarta 10-11 September 2013.

Saptari, Ratna \& Briigitte Holzner. 1997. Perempuan Kerja dan Perubahan Sosial; Sebuah Pengantar Studi Perempuan. Jakarta: Kalyanamitra.

Shields, Vickie Rutledge dan Brenda Dervin. 1993. "Sense-Making in Feminist Social Science Research: A Call to Enlarge the Mothodological Options of Feminist Studies", dalam Women's Studies International Forum, 16(1).

Santrock, John W. 2003. Perkembangan Remaja. Erlangga: Jakarta.

Soelaeman. 1994.Pendidikan dalam Keluarga.Bandung : Alfabet.

Sarwono, Sarlito. 2012 Psikologi Remaja Edisi Revisi. Jakarta: PT. Raja Grafindo Persada.

Sutrisno, Mudji. 2005. Teks-Teks Kunci Estetika: Filsafat Seni. Yogyakarta: Galangpress.

Sutrisno, Mudji dan Hendar Putranto. 2005. Teori-Teori Kebudayaan. Yogyakarta: Kanisius.

Sunarti, E. 2001. Ketahanan Keluarga Dan Pengaruhnya Terhadap Kualitas Kehamilan [Disertasi]. Bogor: Fakultas Pertanian, Institut Pertanian Bogor.

Tambunan, A. P. 2007.Menilai Harga Wajar Saham (Stock Valuation).Penerbit PT. Elex Media.Jakarta. 
Temuan dan Rekomendasi KPAI tentang "Perlindungan Anak di Bidang Perdagangan Anak (Trafficking) dan Eksploitasi Terhadap Anak", http://www.kpai.go.id/artikel/temuan-dan-rekomendasi-kpaitentang-perlindungan-anak-di-bidangperdagangan-anak-traffickingdaneksploitasi-terhadap-anak/, diakses 15 September 2016.

Tong, Rosemari Putnam. 2008. Feminist Thought. Yogyakarta: Jalasutra, Ulfiah, Hubungan Antara Gaya Pengasuhan Orang Tua dengan Pencapaian Status Identitas, Tesis, Pascasarjana Unpad. 2004.

------, 2016. Psikologi Keluarga, Ghalia Indonesia, Bogor.

Woodman, C.B., Collins, S.I., Young, L.S. 1991. The Natural History of Cervical HPV Infection: Unresolved Issues. Nature Reviews Cancer. 